\title{
Evaluasi Metode Shape Contexts pada Media Pembelajaran Interaktif Bangun Datar
}

\author{
Evaluation of Shape Contexts In Two-Dimentional Figure Interactive Learning Media
}

\author{
Tri Septianto \\ Universitas Nahdlatul Ulama Sidoarjo \\ E-mail: triseptianto.ti@unusida.ac.id
}

\begin{abstract}
Abstrak
Shape contexts merupakan salah satu metode shape matching. Pada penelitian ini metode ini diterapkan dalam sebuah media pembelajaran bangun datar prasekolah dasar. Hal ini bertujuan untuk menambah unsur interaktif dan terkesan mengandung kecerdasan buatan dalam sebuah media pembelajaran. Metode ini digunakan untuk mengukur persentase inputan coretan tangan pengguna. Inputan pengguna berupa coretan tangan bidang persegi, lingkaran dan segitiga. Apabila presentase inputan pengguna diatas threshold maka dianggap benar. Threshold yang digunakan yaitu $>70 \%$. Karena masih dalam fase pengembangan maka diperlukan evaluasi terhadap penggunaan metode ini. Evaluasi dilakukan menggunakzan metode $f$-measure. Hasil dari evaluasi dengan metode $f$-measure mendapatkan nilai rata-rata sebesar 0.43 .
\end{abstract}

Kata kunci: shape contexts, f-measure, media pembelajaran, bangun datar

\begin{abstract}
Shape contexts are one of the shape matching methods. In this study this method is applied in a elementary school two-dimentional learning media. The aims to add interactive elements and seem to contain artificial intelligence in it. This method is used to measure the percentage of input of the user's hand strokes. User input in the form of square, circle and triangle hand strokes. If the user input percentage is above the threshold then it is considered correct. The threshold used is $>70 \%$. Because it is still in the development phase, evaluation of the use of this method is needed. Evaluation is done using the f-measure method. The results of the evaluation using the f-measure method get an average value of 0.43 .
\end{abstract}

Keywords: shape contexts, f-measure, learning media, two-dimentional

\section{PENDAHULUAN}

Media pembelajaran interaktif memiliki dua komponen penting yaitu sebagai media pembelajaran dan media interaktif. Media pembelajaran merupakan semua alat yang digunakan untuk menunjang proses belajar. Sedangkan media interaktif merupakan produk dan layanan digital yang merespon aksi dari pengguna dengan konten seperti teks, animasi, video dan audio [1]. Berdasarkan beberapa perkembangan teknologi media pembelajaran interaktif termasuk media hasil teknologi [2]. Media interaktif dapat diterapkan di berbagai macam platform pada semua bidang teknologi. Sehingga media pembelajaran interaktif bisa diartikan sebagai alat penunjang proses belajar dengan memanfaatkan media digital.

Sebagai media interaktif salah satu unsur yang harus dimiliki adalah unsur interaktivitas, dimana sebuah output berasal dari input pengguna. Pada penelitian ini dilakukan percobaan untuk menambah interaktivitas dengan cara menyisipkan sebuah salah satu cabang keilmuan computer vision kedalam sebuah media pembelajaran bangun datar untuk anak prasekolah dasar. Hal ini ditujukan agar pada media pembelajaran ini lebih menarik dan sebagai salah satu bentuk penerapan computer vision pada bidang pendidikan. Salah satu cabang tersebut adalah rekognisi. Hal ini ditunjang karena telah banyak penelitian tentang rekognisi dengan obyek yang bervariasi. Adapun penelitian tersebut antara lain rekognisi pengenalan plat 
nomer [3], rekognisi karakter aksara jawa [4], rekognisi teks pada logam [5], rekognisi buah [6], rekognisi pada prasasti angka tahun pada peninggalan Kerajaan Majapahit [7], rekognisi coretan tangan: Mayalam [8], Persia [9] dan Bangla [10]. Selain obyek, metode rekognisi juga sudah banyak diteliti misal seperti rekognisi dengan menggunakan GLCM-SVM [6], KNN [7] dan CNN $[8,9,10]$. Semua penelitian yang telah disebutkan masih belum diimplementasikan untuk menunjang sebuah media pembelajaran.

Pada penelitian ini, kami melakukan penerapan rekognisi dengan obyek yang berbeda yaitu coretan tangan pengguna dengan bentuk bidang pada sebuah media pembelajaran bangun datar. Metode yang dipilih pada penelitian ini yaitu shape contexts. Metode ini dipilih karena mengukur kesamaan dan korespondensi bentuk dari susunan titik yang terhubung $[11,12]$. Shape Contexts secara garis besar mempunyai lima tahap dalam proses rekognisi antara lain mencari semua titik tepi bentuk, menghitung konteks bentuk, menghitung cost matriks, mencari bentuk yang sesuai dengan nilai minimal dari total cost dan melakukan transformasi pemodelan sebuah bentuk. Dikarenakan metode ini diterapkan pada sebuah media pembelajaran untuk menunjang sebuah media pembelajaran. Pada penelitian ini perlu dilakukan evaluasi terhadap metode tersebut. Evaluasi yang dilakukan berkaitan dengan akurasi. Untuk evaluasi akurasi pada penelitian ini menggunakan metode $f$-measure. Metode ini dipilih karena berdasarkan perbandingan terhadap bobot presisi dan recall.

\section{METODE PENELITIAN}

Untuk mempermudah proses penelitian, kami membaginya menjadi lima proses antara lain: observasi, pembuatan antarmuka pengguna, pembuatan data pelatihan, penerapan metode shape contexs serta proses evaluasi hasil akurasi. Untuk alur urutan proses bisa dilihat pada gambar 1.

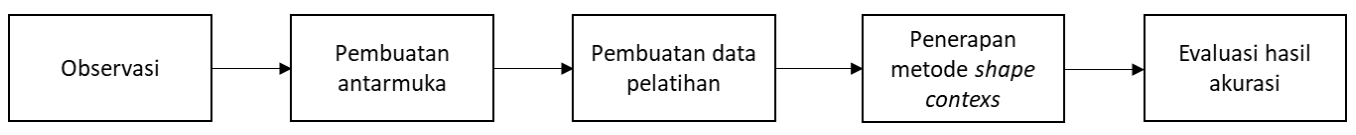

Gambar 1 Alur urutan proses

\subsection{Observasi}

Observasi dilakukan pada dua sekolah yaitu Kelompok Belajar Aisyiyah 33 dan Ananda Surabaya. Dari hasil penilaian terhadap kegunaan, kemudahan penggunaan, kemudahan belajar dan kepuasaan media pembelajaran yang dibuat mendapatkan nilai yang sangat memuaskan [13]. Dari observasi tersebut diperoleh saran agar dilakukan evaluasi terhadap hasil rekognisi serta memperbaiki antarmuka pengguna.

\subsection{Pembuatan antarmuka pengguna}

Pada tahap ini, kami mencoba melakukan realisasi saran dari pengguna untuk memperbaiki antarmuka pengguna. Antarmuka pengguna kami membagi menjadi tiga bagian, yaitu bagian gambarkan ulang lingkaran, gambarkan ulang persegi dan gambarkan ulang segitiga. Untuk contoh antarmuka pengguna yang digunakan seperti gambar 2. 


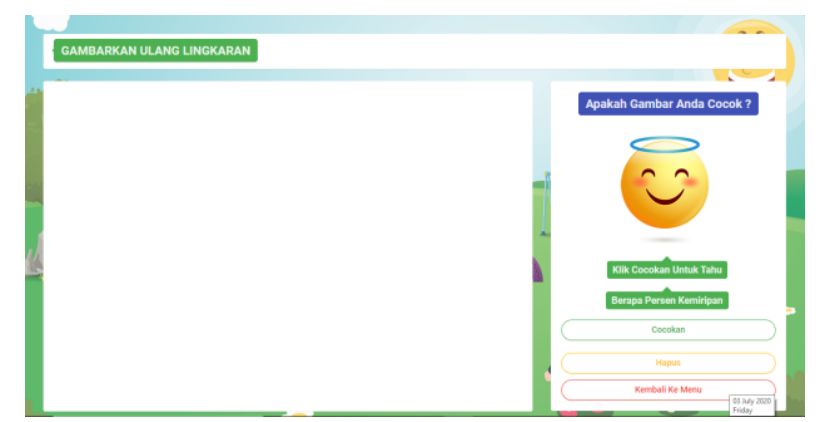

Gambar 2 Antarmuka pengguna gambarkan ulang lingkaran

\subsection{Pembuatan data pelatihan}

Pada tahap ini merupakan pembuatan data pelatihan. Data pelatihan dibuat dengan melakukan coretan bidang lingkaran, persegi dan segitiga seperti gambar 3 .

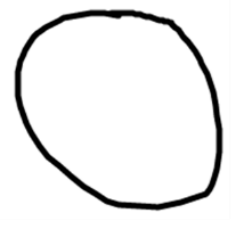

(lingkaran)

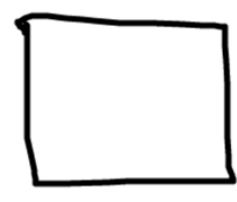

(persegi)



(segitiga)

Gambar 3 Contoh data pelatihan

Pada gambar 3 setiap coretan gambar bidang dikoversi menjadi sebuah kumpulan nilai yang berisi posisi koordinat suatu garis atau titik yang tergambar. Lalu kumpulan nilai tersebut disimpan kedalam file json.

\subsection{Penerapan metode shape contexts}

Pada tahap ini menjelaskan tentang metode shape contexts dalam melakukan rekognisi. Untuk mempermudah penjelasan pada tahap ini bisa dilihat pada blok diagram seperti pada gambar 4.



Pada blok diagram gambar 4 terdiri dari tiga tahap yaitu inputan, konversi ke nilai koordinat dan file json. Inputan merupakan tahap seorang pengguna melakukan coretan tangan. Konversi ke nilai koordinat merupakan proses mengubah seluruh coretan tangan menjadi nilai koordinat. Sedangkan file json digunakan untuk menyimpan semua nilai koordinat hasil konversi coretan tangan.

Blok diagram gambar 4 digunakan untuk tahapan pelatihan dan pengujian. File json yang dihasilkan pada tahap pelatihan disimpan dan digunakan saat pengujian. Jadi pada tahap pengujian metode shape contexts melakukan perhitungan terhadap file json data pelatihan yang sudah ada dengan file json dari pengujian. Untuk memahami konversi nilai koordinat dari inputan pengguna sebenarnya hampir sama seperti melakukan pengkodean canvas yang berisi nilai kemudian menghasilkan sebuah bentuk bidang. Untuk menggambar sebuah lingkaran biasanya menggunakan seperti fungsi (1). 
canvas. arc ( $x, y, r$, sAngle, eAngle, counterclockwise)

Pada fungsi (1) mempunyai parameter $x$ merupakan koordinat $x, y$ merupakan koordinat $y, r$ merupakan radius, sAngle merupakan posisi angle pertama, eAngle merupakan posisi angle terakhir dan counterclockwise merupakan menggambar searah jarum jam atau tidak biasanya pada parameter ini bersifat opsional. Misal $x=100, y=75, r=50$, sAngle $=0$, eAngle $=2 *$ Math.PI. Bidang yang dihasilkan seperti pada gambar 5 .

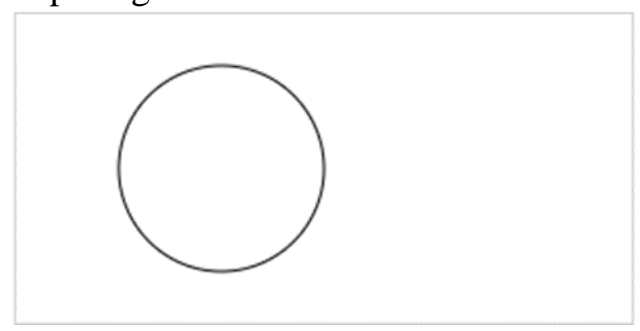

Gambar 5 Contoh gambar lingkaran

Untuk menggambar persegi atau persegi panjang bisa menggunakan fungsi (2).

canvas. rect $(x, y$, width, height);

Pada fungsi (2) mempunyai parameter $x$ merupakan koordinat $x, y$ merupakan koordinat $y$, width merupakan panjang, height merupakan lebar. Misal $x=50, y=50$, width $=150$, height $=80$. Bidang yang dihasilkan seperti pada gambar 6 .

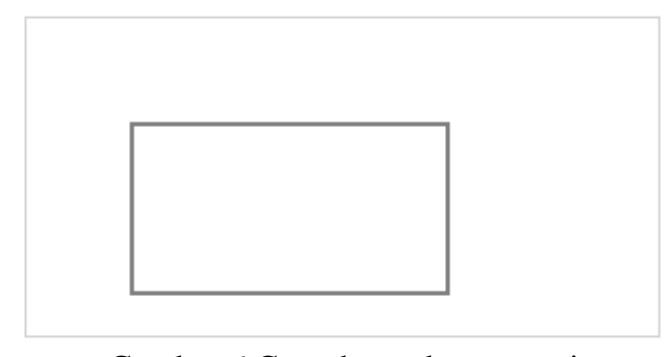

Gambar 6 Contoh gambar persegi

Sedangkan untuk menggambar segitiga biasanya menggunakan fungsi (3).

$$
\text { canvas. triangle(line } 1(x 1, y 1) \text {, line } 2(x 2, y 2) \text {, line }(x 1, y 2)) \text {; }
$$

Pada fungsi (3) terdapat tiga parameter yang besifat fungsi dengan mempunya nilai $x$ dan $y$ yang menunjukkan sebuah koordinat. Tiga parameter tersebut merupakan garis-garis yang membentuk segitiga. Misal pada line 1 mempunyai nilai $x l=100$ dan $y l=300$, pada line2 mempunyai nilai $x 2=300$ dan $y 2=300$ sedangkan pada line3 mempunyai nilai $x 1=100$ dan $y 2=300$. Maka gambar yang dihasilkan seperti gambar 7 . 


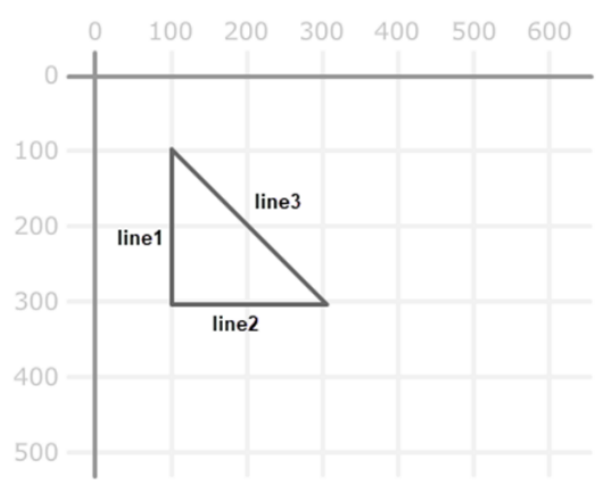

Gambar 7 Contoh gambar segitiga

\subsection{Proses evaluasi hasil rekognisi}

Pada tahap ini kami melakukan evaluasi dengan tiga skema pengujian seperti pada gambar 8 .

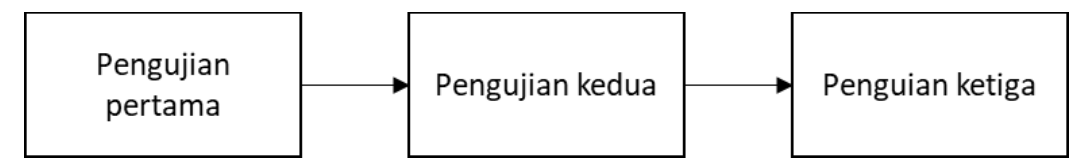

Gambar 8 Skema pengujian

Skema pengujian pertama kami melakukan ujicoba dengan menggunakan inputan bidang dan data pelatihan yang sama. Untuk blok diagram skema pengujian pertama bisa dilihat pada gambar 9 .

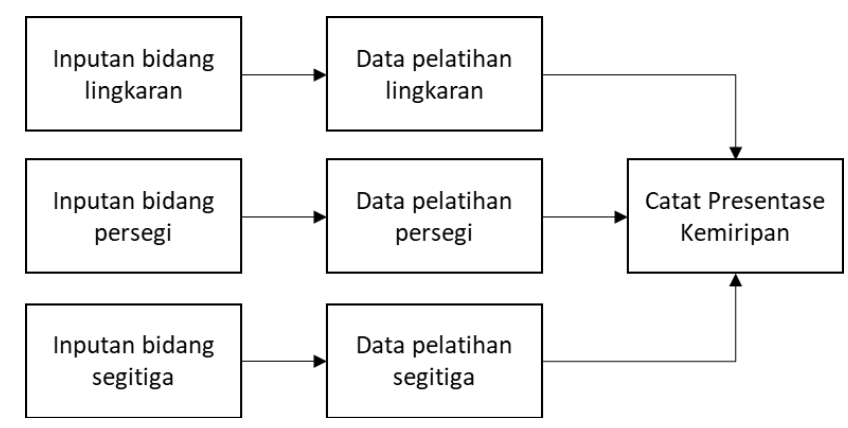

Gambar 9 Skema pengujian pertama

Pada gambar 9, inputan bidang lingkaran diujikan dengan data pelatihan lingkaran. Inputan bidang persegi dengan data pelatihan persegi, sedangkan inputan bidang segitiga dengan data pelatihan segitiga. Kemudian semua hasil dicatat.

Pada skema pengujian kedua kami melakukan ujicoba dengan menggunakan dua data pelatihan bidang yang berbeda dengan inputan bidangnya. Untuk blok diagram pengujian kedua bisa dilihat pada gambar 10 . 


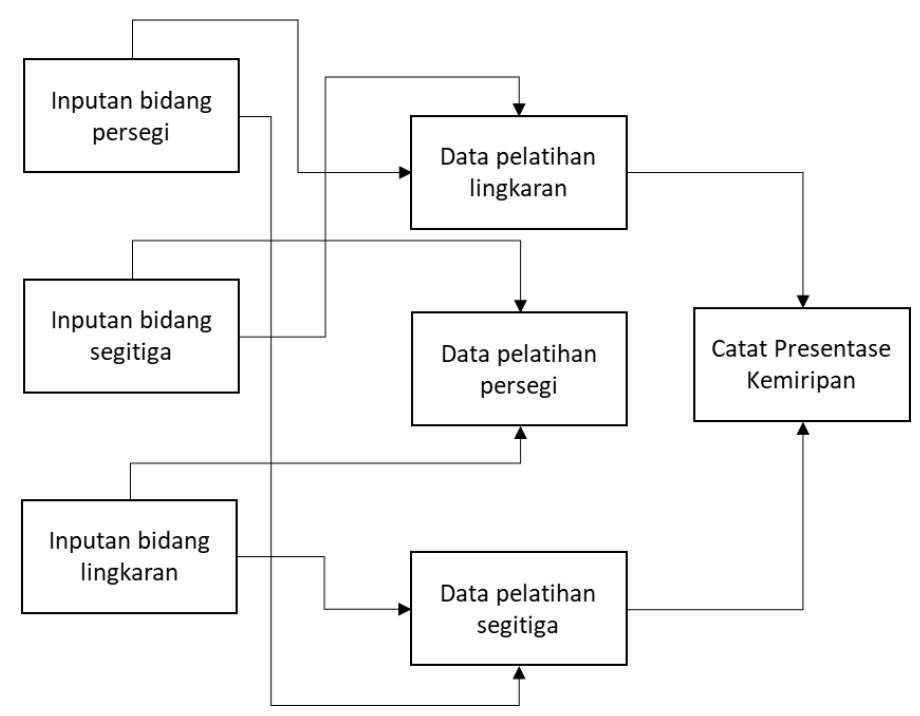

Gambar 10 Skema pengujian kedua

Pada gambar 10, inputan bidang persegi diujikan dengan data pelatihan lingkaran dan segitiga. Inputan bidang segitiga diujikan dengan data pelatihan lingkaran dan persegi. Sedangkan inputan bidang lingkaran diujikan dengan data pelatihan segitiga dan persegi. Pada tahap ini ditentukan threshold untuk menentukan suatu coretan termasuk dikenali atau tidak berdasarkan persentase kemiripannya. Threshold yang dipakai $>70$, jika persentase kemiripan memenuhi nilai threshold, maka dianggap dikenali. Sedangkan pada skema pengujian tahapan ketiga kami mencoba melakukan evaluasi metode shape context dengan menggunakan metode f-measure.

\section{HASIL DAN PEMBAHASAN}

Shape contexts merupakan metode yang mengakumulasi tingkat kemiripan dari titiktitik yang dihasilkan oleh sebuah obyek [11,12]. Sehingga yang metode ini butuhkan dalam proses rekognisi hanyalah nilai dari koordinat dari suatu data pelatihan dan pengujian. Pada bagian sebelumnya semua data tersebut sudah disimpan dalam bentuk file json. Untuk blok diagram akumulasi metode shape contexts terhadap data pelatihan dan pengujian bisa dilihat pada gambar 11.

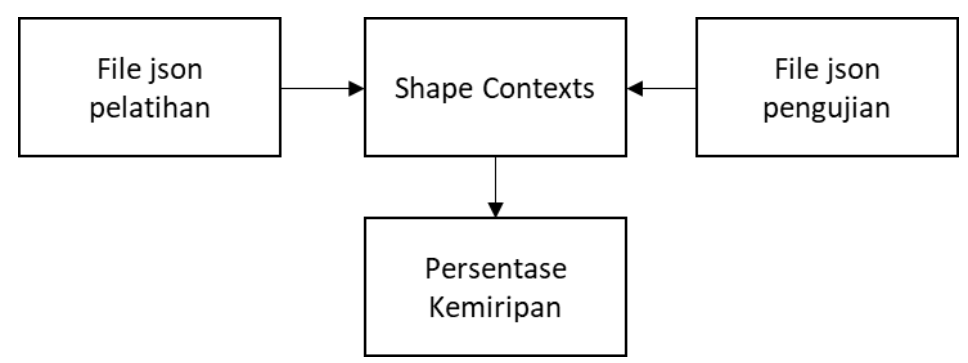

Gambar 11 Blok diagram perhitungan metode shape contexts 
Untuk melihat ilustrasi sebuah bidang dikonversi menjadi nilai koordinat bisa dilihat pada gambar 12.

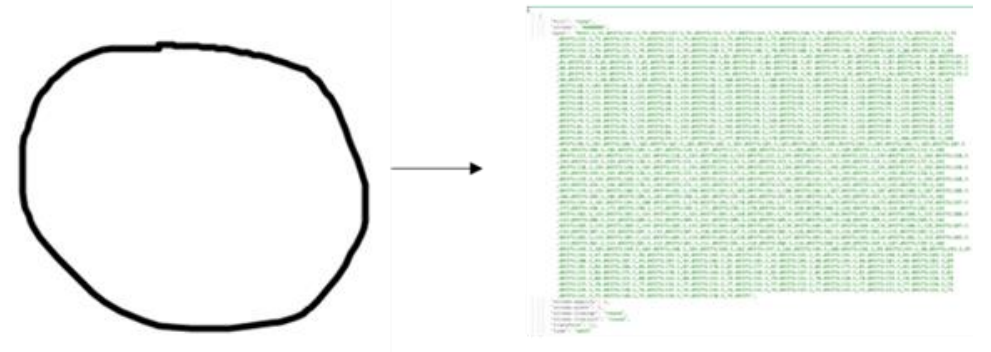

Gambar 12 Ilustrasi perubahan inputan bidang ke nilai koordinat

Pada gambar 12, data nilai koordinat tersebut disimpan kedalam format json. Dari data file json tersebut hasil persentase kemiripan dihasilkan. Sehingga apabila media pembelajaran tersebut digunakan untuk melakukan rekognisi terhadap inputan bidang akan menghasilkan persentase kemiripan seperti pada gambar 13.

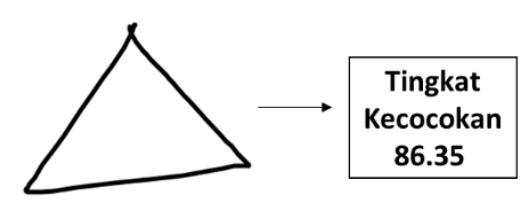

Gambar 13 Contoh data pengujian

Skema pengujian pertama dilakukan 10 kali pengujian perinputan bidang. Pada skema pengujian pertama hasil persentase dicatat seperti pada blok diagram gambar 9. Skema pengujian pertama bertujuan untuk melihat akurasi data pelatihan mengenali inputan bidang yang sama. Untuk hasil skema pengujian tahap pertama bisa dilihat pada tabel 1.

Tabel 1 Hasil skema pengujian pertama

\begin{tabular}{|c|c|c|c|}
\hline Percobaan ke - & Lingkaran & Segitiga & Persegi \\
\hline 1 & 82.31 & 86.35 & 88.7 \\
\hline 2 & 91.13 & 89.08 & 86.55 \\
\hline 3 & 87.04 & 74.76 & 72.16 \\
\hline 4 & 88.6 & 76.13 & 75.17 \\
\hline 5 & 78.6 & 87.8 & 85.01 \\
\hline 6 & 80.85 & 75.11 & 84.05 \\
\hline 7 & 89.22 & 89.76 & 87.98 \\
\hline 8 & 78.77 & 71.31 & 90.54 \\
\hline 9 & 90.87 & 76.23 & 81.59 \\
\hline 10 & 78.66 & 83.62 & 80.38 \\
\hline Rata-rata & 83.64 & 81.71 & 81.94 \\
\hline
\end{tabular}

Pada tabel 1 diperoleh rata-rata persentase kemiripan dari bidang lingkaran sebanyak 83.64, bidang segitiga sebanyak 81.71 dan bidang persegi sebanyak 81.94 .

Pada skema pengujian kedua dilakukan 10 kali pengujian dengan perinputan bidang dan mencatat semua hasilnya seperti pada blok diagram gambar 10 . Serta menambahkan data skema 
pengujian pertama kedalam skema pengujian kedua. Pada skema pengujian kedua diperoleh total 30 kali coretan tangan perbidang. Sehingga pada skema pengujian tahap kedua diperoleh sebuah confusion matrix seperti tabel 2.

Tabel 2 Hasil skema pengujian tahap pertama

\begin{tabular}{|c|c|c|c|c|}
\hline \multirow{2}{*}{\multicolumn{2}{|c|}{ 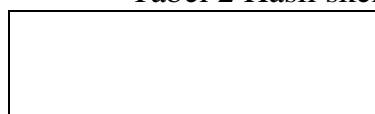 }} & \multicolumn{3}{|c|}{ Aktual } \\
\hline & & Lingkaran & Segitiga & Persegi \\
\hline \multirow{3}{*}{ Prediksi } & Lingkaran & 10 & 0 & 10 \\
\hline & Segitiga & 0 & 10 & 0 \\
\hline & Persegi & 10 & 0 & 10 \\
\hline
\end{tabular}

Pada tabel 2 pada inputan bidang persegi masih bisa dikenali pada data pelatihan lingkaran sedangkan inputan bidang lingkaran masih bisa dikenali pada data pelatihan persegi. Hal ini bisa disebabkan oleh nilai koordinat yang hamper sama saat dilakukan perhitungan.

Pada gambar 14 merupakan contoh bidang persegi dan lingkaran dengan posisi pixel yang sama.

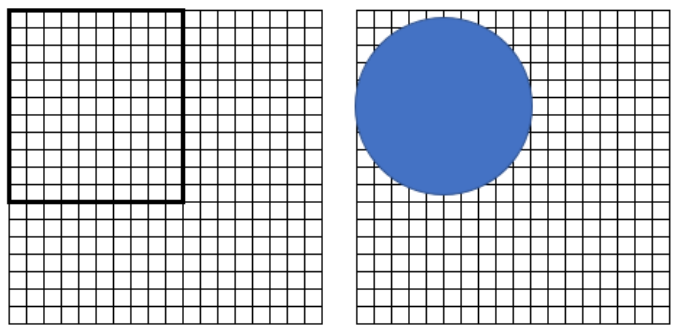

Gambar 14 Persegi dan lingkaran

Persegi dan lingkaran pada gambar 14 apabila disatukan membentuk gambar 15. Pada gambar 15 sudah terlihat bahwa ada beberapa kordinat yang berdekatan.
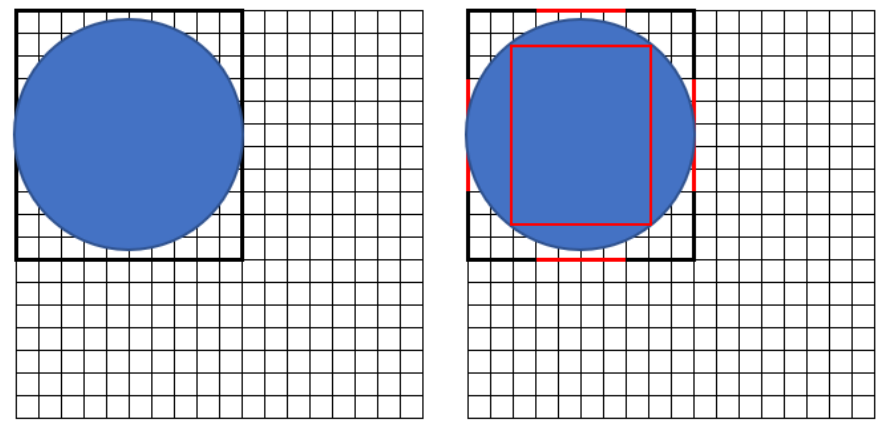

Gambar 15 Analisa kedekatan path antara persegi dan lingkaran

Dari tabel 2 dilanjutkan untuk mencari nilai presisi dan recall. Kedua nilai tersebut akan digunakan untuk mencari nilai $f$-measure. Untuk rumus $f$-measure bisa dilihat pada (1).

$$
f-\text { measure }=2 x \frac{\text { presisi } x \text { recall }}{\text { presisi }+ \text { recall }}(1)
$$

Metode $f$-measure dipilih dikarenakan bisa digunakan untuk kasus multiple class dikarenakan pada penelitian ini terdapat tiga kelas yaitu lingkaran, persegi dan segitiga. Metode ini juga merupakan mempertimbangkan nilai dari presisi dan recall. Untuk melihat nilai presisi, recall dan f-measure bisa dilihat pada tabel 3 . 
Tabel 3 Nilai f-measure dari tabel 2

\begin{tabular}{|c|c|c|c|}
\hline Bidang & Presisi & Recall & F-Measure \\
\hline lingkaran & 0.5 & 0.33 & 0.4 \\
\hline segitiga & 1 & 0.33 & 0.5 \\
\hline persegi & 0.5 & 0.33 & 0.4 \\
\hline \multicolumn{4}{|c|}{ Rata-rata } \\
\hline
\end{tabular}

Dari tabel 3 bisa dilihat bahwa hasil dari nilai $f$-measure bidang lingkaran sebesar 0.4 , bidang segitiga sebesar 0.5 dan bidang persegi sebesar 0.5. Rata-rata nilai $f$-measure sebesar 0.43 .

\section{KESIMPULAN DAN SARAN}

Shape contexts merupakan metode yang menggunakan nilai koordinat suatu bidang untuk menentukan tingkat kemiripan. Pada hasil pengujian tahap ketiga diperoleh nilai rata-rata $f$-measure sebesar 0.43. Hal ini dikarenakan pada gambar ulang persegi masih bisa mengenali lingkaran sedangkan pada gambar ulang lingkaran masih bisa mengenali persegi sehingga mempengaruhi nilai presisi dan recall. Dengan demikian maka perlu adanya kajian terhadap metode lain atau optimasi terhadap metode yang sama dengan study kasus yang sama.

\section{DAFTAR PUSTAKA}

[1] Eskicioglu, A.M. \& Kopec, D. (2003). The Ideal Multimedia-Enabled Classroom: Perspectives from Psychology, Education, and Information Science. Journal of Educational Multimedia and Hypermedia, 12(2), 199-221. Norfolk, VA: Association for the Advancement of Computing in Education (AACE).

[2] Arsayd, Azhari., 2009, Media Pembelajarans, PT. RajaGrafindo Persada, Jakarta.

[3] P. S. Ha and M. Shakeri, "License Plate Automatic Recognition based on edge detection," 2016 Artificial Intelligence and Robotics (IRANOPEN), Qazvin, 2016, pp. 170-174, doi: 10.1109/RIOS.2016.7529509.

[4] Rismiyati, Khadijah and A. Nurhadiyatna, "Deep learning for handwritten Javanese character recognition," 2017 1st International Conference on Informatics and Computational Sciences (ICICoS), Semarang, 2017, pp. 59-64, doi: 10.1109/ICICOS.2017.8276338.

[5] J. Kronenberger, D. Malysiak and U. Handmann, "Text and character recognition on metalsheets," 2017 IEEE International Conference on Information and Automation (ICIA), Macau, 2017, pp. 392-397, doi: 10.1109/ICInfA.2017.8078940.

[6] T. Septianto, E. Setyati, and J. Santoso, "Digit Classification of Majapahit Relic Inscription using GLCM-SVM,” vol. 1, no. 2, pp. 46-54, 2018.

[7] Erwin, M. Fachrurrozi, A. Fiqih, B. R. Saputra, R. Algani and A. Primanita, "Content based image retrieval for multi-objects fruits recognition using k-means and k-nearest neighbor," 2017 International Conference on Data and Software Engineering (ICoDSE), Palembang, 2017, pp. 1-6, doi: 10.1109/ICODSE.2017.8285855. 
[8] P. P. Nair, A. James and C. Saravanan, "Malayalam handwritten character recognition using convolutional neural network," 2017 International Conference on Inventive Communication and Computational Technologies (ICICCT), Coimbatore, 2017, pp. 278-281, doi: 10.1109/ICICCT.2017.7975203.

[9] Z. Shokoohi, A. M. Hormat, F. Mahmoudi and H. Badalabadi, "Persian handwritten numeral recognition using Complex Neural Network and non-linear feature extraction," 2013 First Iranian Conference on Pattern Recognition and Image Analysis (PRIA), Birjand, 2013, pp. 1-5, doi: 10.1109/PRIA.2013.6528447.

[10] M. A. H. Akhand, M. M. Rahman, P. C. Shill, S. Islam and M. M. Hafizur Rahman, "Bangla handwritten numeral recognition using convolutional neural network," 2015 International Conference on Electrical Engineering and Information Communication Technology (ICEEICT), Dhaka, 2015, pp. 1-5, doi: 10.1109/ICEEICT.2015.7307467.

[11] Belongie and Malik, "Matching with shape contexts," 2000 Proceedings Workshop on Content-based Access of Image and Video Libraries, Hilton Head Island, SC, USA, 2000, pp. 20-26, doi: 10.1109/IVL.2000.853834.

[12] S. Belongie, J. Malik and J. Puzicha, "Shape matching and object recognition using shape contexts," in IEEE Transactions on Pattern Analysis and Machine Intelligence, vol. 24, no. 4, pp. 509-522, April 2002, doi: 10.1109/34.993558.

[13] T. Septianto, "EVALUASI MEDIA PEMBELAJARAN BERBASIS HYBRID DENGAN USE QUESTIONNAIRE - STUDI KASUS: AYO BELAJAR BANGUN DATAR PRA SD," in Seminar Pendidikan Nasional SMK Negeri 9 Kota Malang, 2017, vol. 1, pp. 358-367. 